\title{
Certifying the commons: eco-certification, privatization, and collective action
}

\author{
$\underline{\text { Paul Foley }}^{1}$ and Bonnie McCay ${ }^{2}$
}

\begin{abstract}
We examine new dynamics of privatization and collective action in common pool resource situations facilitated by the nonstate multistakeholder institutions of the Marine Stewardship Council (MSC), the global leader in sustainability certification for wild caught seafood. Through a review of the literature and two case studies of fishing cooperatives in Baja California Sur, Mexico and on Fogo Island in the Canadian Province of Newfoundland and Labrador (NL), we advance two interrelated arguments. First, certification and eco-labeling institutions privatize fisheries governance in largely unexamined ways through the injection of new forms of exclusive rights or privileges into common pool resource situations already complicated by access and property privileges, creating conditions for confusion and conflict as well as cooperation. Second, the MSC whole stock definition of sustainability places greater demands on certification clients for engaging in collective action by encouraging coordination over all social extractions from targeted fish stocks. Although rules encouraging collective action in common pool situations militate against the narrow private capture of certificate and eco-label rights, they also undermine the ability of small-scale and community-based fisheries that are embedded in larger unhealthy fishery contexts to acquire the right to the MSC stamp of sustainability. We conclude that MSC certification and ecolabeling create new institutions of private property rights and collective action, which can result in exclusionary practices, inclusionary collective action, or both. Much will depend on the specific common pool context and history of the fishery.
\end{abstract}

Key Words: Baja California Sur, Mexico; collective action; common pool resources; commons; community-based fisheries; cooperatives; environmental certification; environmental governance; fisheries; Fogo Island, Newfoundland and Labrador, Canada; governance; Marine Stewardship Council; MSC; northern shrimp; privatization; property rights; spiny lobster; sustainable

\section{INTRODUCTION}

Fisheries are at the forefront of policy experimentation in the privatization of natural resources characterized as commons. For those who still view the main problem of fisheries governance as a tragedy of the commons problem, the only effective solution is to establish secure, exclusive, clearly bounded, enforceable, and transferable property rights to fish resources (Moloney and Pearse 1979). Privatization has been manifested in fisheries most prominently through the widespread use of individual transferable quotas (ITQs) systems, which create a type of privatized exclusive right to a catch share, which can be traded as a commodity (Sumaila 2010). Although ITQs have helped address problems of overcapitalization, the efficacy of ITQs in improving conservation and socioeconomic outcomes remains subject to ongoing debate and research. Concerns about the negative socioeconomic effects of ITQs on communities and fisherydependent livelihoods have led to innovations in communitybased fisheries management, such as the Community Quota program for the Gulf of Alaska communities and to calls for more systematic community-oriented innovations in catch share policies and design (Ecotrust 2011). These developments illustrate the importance of examining relationships between two significant trends in resource and environmental governance: (1) the increasing reliance on private sector market mechanisms and (2) greater participation by local communities (McCay 2004). Although much research has examined the relationship between privatization and communities in resource access governance, hardly any research has examined the relationship between privatization and communities in another important form of fisheries governance, sometimes conceptualized as privatization: environmental certification and eco-labeling systems administered by nongovernmental organizations (NGOs). We seek to advance the understanding of the interaction between this form of fisheries governance and small-scale and community-based fisheries.

To what extent can certification and eco-labeling programs administered by NGOs be conceptualized as privatization of fisheries governance? In what ways and with what consequences does this form of privatization interact with existing 'commons' institutions and relationships? Finally, what effects does this form of privatization have on small-scale and community-based fisheries, which are widely considered vulnerable to the ITQ form of privatization? Drawing on research on Marine Stewardship Council certification and eco-labeling, we focus on the intersection of the creation of a new form of exclusive rights or privileges, i.e., the right to claim and use certification, with different forms of fisheries commons. Through an examination of two community-based cooperatives engaged in the program, we argue that the injection of new privatized property rights into already existing Common Pool Resource situations creates conditions for exclusion, confusion, and conflict but also for inclusion, cooperation, and collective action. Unlike ITQs, MSC certification and eco-labeling implementation rules and methodology encourage participatory and inclusive practices, which enhance potential for relatively democratic outcomes. In particular, the MSC's whole-stock definition of sustainability scales up the unit of certification to larger social-ecological fishery units, putting greater demands on certification clients to engage in collective action.

We therefore developed two core arguments. First, certification and eco-labeling privatizes fisheries governance in new ways through the injection of exclusive rights or privileges into common pool resource situations. Second, certification rules encourage coordination and collective action encompassing all 
social extractions from targeted fish stocks. The extent to which these dynamics result in exclusionary practices, collective action or dynamic patterns of both, in the implementation of certification will be shaped by the particular common pool context and history of the fishery.

\section{PRIVATIZATION, MARINE STEWARDSHIP COUNCIL (MSC) CERTIFICATION, AND COMMON POOL RESOURCES}

Philosophical foundations of and economic justifications for establishing governance through voluntary market mechanisms have been influenced by neo-liberal ideas and politics, which eschew mandatory state regulation and promote the use of the private sector over the public sector in ownership and in the provision of goods and services, including governance functions. Following trends in agriculture and forestry in the 1990s, voluntary environmental certification standards and product ecolabeling initiatives are spreading through global seafood systems. The MSC, a not-for-profit charity registered in the United Kingdom by the World Wildlife Fund (WWF) and Unilever in 1999 , leads the certification movement in wild-caught fisheries (Ponte 2012). To address the problem of global fisheries depletion and the perceived lack of effective state management of fisheries, the MSC's founders created an institutional approach focused, not on instruments of traditional government management institutions and law, but on market incentives and expected economic benefits of certification and product labeling. An overall goal was and is to encourage fisheries to voluntarily conform to a standard of environmental sustainability. Fisheries can apply for third-party assessment against two standards that the MSC administers. The first is the Environmental Standard for Sustainable Fishing, which consists of Principles and Criteria for Sustainable Fishing against which fisheries are assessed by accredited third-party certification organizations. The second is the MSC Chain of Custody Standard for Seafood Traceability, which provides a template for auditing the movement of certified products from landing to various points of sale, to verify that products sold with the MSC eco-label originated from certified fisheries. The MSC's sustainable fishery standard focuses on ecological and management principles and criteria, with three categories, (1) measuring the health of the stock, (2) impacts on marine ecosystems, and (3) the efficacy of the management system. Unlike the case in the Forest Stewardship Council (FSC), the MSC decided not to include social and community-oriented principles, criteria, and indicators in its standard of sustainability, a complaint of some fisheries organizations (Grader et al. 2003, Ponte 2008).

The MSC is often conceptualized as an example of a growing set of private governance institutions operating at the global or transnational level (Kalfagianni and Pattberg 2013). The term privatization is commonly invoked to conceptualize two separate governance components within certification and labeling programs. First, privatization can refer to the nonstate or nongovernmental character of the governance institutions under study, with concepts of public/private generally used synonymously with state/nonstate. In the MSC, and similar organizations like the FSC and Aquaculture Stewardship Council (ASC), rule-making authority is not formally derived from nation-state sovereignty, but from nongovernmental organizations administering third-party standards (Cashore 2002). In this way,
MSC certification and eco-labeling privatizes fisheries governance in nonstate multistakeholder institutions. Second, privatization can refer to the voluntary, market-oriented compliance and enforcement mechanisms used by these governance institutions. Uptake and compliance with rules and standards administered by the MSC and similar organizations are designed to be driven not by legal or regulatory power and authority of state sovereignty, but by the power of market incentives, i.e., market actors using tools of certification and ecolabels to verify the sustainability of commodity products in efforts to attract, and materially benefit from, changing purchasing behavior of buyers and consumers. Although the use of privatization to conceptualize nonstate and market-oriented characteristics of this form of governance is instructive, a third dimension of privatization, which occurs at the level of implementation, has yet to be adequately theorized and examined: the privatization of governance in new exclusive privatized property rights that certification confers on certificate holders. Certificates and eco-labels are defined by rules of exclusivity and are governed by specified usage rules. One of the most important implications of these privatized components of governance is that decisions and choices have to be made to determine who gains access to the right to use certificates and ecolabels. Little research, however, has examined the "micro" political and equity dimensions of these rules, rights, obligations, and relationships.

We suggest that the implementation of MSC certification will be shaped in crucial ways by interactions between exclusivity of privatized certification institutions and the collective socialecological characteristics of specific commons situations. The concept of 'the commons' refers to social-ecological situations involving common pool resources (CPRs) and institutions that share access rights and/or obligations (McCay 2000). Typical natural resource examples include bodies of water, forests, oil and gas reservoirs, and fish stocks. Common pool resources are resources that have the features of 'nonexcludability,' which means that limiting others' use of and access to the same resources is costly and difficult, and 'subtractability,' whereby each user is able to subtract from the amount or quality available to another (Feeny et al. 1990). Such a resource may be owned, used, and/or managed under a wide variety of institutional arrangements. 'Common property' refers to an institution that preserves some element of shared ownership or use rights but is neither open access or fully privatized, a form of property sometimes viewed as 'communal property' (Feeny et al. 1990). Common pool resources may be treated as common property but they could be other forms, including open access, private property, or state property (Feeny et al. 1990). It is also important to note that distinctions between different types of property rights can blur in real social situations and more than one type of property right can be observed for particular resources (McCay 2000). The issue of MSC certification as privatization comes up through the intersection of the initial determination of clients and units of certification in the certification application process and the common pool nature of the resources involved.

For the matter of property rights, certification and eco-labeling inject new privatized property rights into already existing commodity relations and commons situations when clients acquire exclusive rights to use an MSC certificate and eco-label. 
Clients become certificate holders upon successful assessment, and the certificate document confers rights and responsibilities on the certificate holder (Marine Stewardship Council Executive 2005a, Foley 2012). Upon receipt of a certificate, the client has the right to claim the fishery for which they hold a certificate as a "Well Managed and Sustainable Fishery" in accordance with the MSC principles and criteria for sustainable fishing. An important privilege rule concerns certificate exclusivity, which means "only those parties or categories of parties...from the assessed fishery that are identified by reference to or listed on a valid fishery certificate by the certification body are entitled to apply for chain of custody certification and subsequent use of the MSC logo" (Marine Stewardship Council Executive 2005b:3). The MSC's subsidiary company, Marine Stewardship Council International Limited (MSCI), licenses the use of the MSC's trademarked eco-label on behalf of the MSC and collects logo licensing and royalty fees from users. Marine Stewardship Council International Limited's control over access to and use of MSC certificates and label resembles a kind of property right that fishery client organizations attain by entering into a license agreement with the MSCI. As one MSC representative explained, "Some people think that if fishery $\mathrm{X}$ is certified, then anyone engaged in that fishery ought to get access [to the eco-label]. But the MSC does not work that way" (P. Foley, personal communication). In the MSC program, "clients are entitled to exclusive ownership of certification. We don't promote or like this," the official added, while also highlighting the problem of free-riders potentially benefiting from the certification (P. Foley, personal communication). Clients gain a powerful position in the process because organizations applying for certification are entitled to provide the names of parties from the assessed fishery that can use the certificate. At one level, then, implementing voluntary certification and labeling in specific contexts requires a boundary setting that is inherently inclusionary and exclusionary (Guthman 2004, 2007). However, the MSC recognizes potential equity dilemmas and advises certification bodies that:

\section{It is desirable for assessment contracts to contain reasonable arrangements to allow for others, either pre- existing fishers within the same 'scope of assessment' or new participants in the unit of certification, to have access to the certificate number. Reasonable arrangements may include agreement to payment of a fair proportion of the assessment costs and commitment to addressing conditions and subsequent corrective actions (Marine Stewardship Council Executive 2005b:3).}

The MSC acknowledges that the key question for the client and certification body is: "assuming the assessment is successful, what and/or who will be certified? The answer to this question may include named species, caught by named methods from named stocks, by named vessels or companies" (Marine Stewardship Council Executive 2005b:1).

The answer to the question of whom or what will be certified in a fishery is not necessarily obvious because of the common pool nature of many fisheries resources. Features of nonexcludability and subtractibility come up in determining units of certification, the definition of which implies an encompassing social-ecological unit, which tends to be very large and diverse. Given the common pool nature of the resource and the strong likelihood that some sort of common property systems exist, a wider variety of actors can often be defined as part of a fishery or unit of certification than might be typical in terrestrial, e.g., farms and forests, and aquaculture systems. Issues of scale and system interaction are crucial in the MSC's definition of a unit of certification, which identifies the social-ecological system that makes up a fishery. The MSC's official definition of the unit of certification is:

\begin{abstract}
The fishery or fish stock (= biologically distinct unit) combined with the fishing method/gear and practice (= vessels $(s))$ pursuing that stock). At its simplest, a single vessel could be the unit of certification, though more likely a number of vessels in the same fishery will probably be assessed.(MSC 2010:1).
\end{abstract}

The whole-stock management approach distinguishes MSC certification from other certifications in that it facilitates scaling to larger geographic units and a wide range of groups (Steering Committee 2012). This benefits the MSC and seafood markets by potentially facilitating the certification of larger volumes of fish than might be the case if the catch of individual operators and small-scale fisheries were certified. However, using the boundaries of a wild fish stock or defined population for the assessment creates problems for the socioeconomic component of the system. Social and institutional scales and systems are more open-ended and ambiguous, involving as they do distinct fishing methods, practices, vessels, and communities that may be competing with others over access to, and use of, the common pool fish stock.

The practical and political questions then become: who within the fishery asks for an assessment, the client, and who, if certification takes place, has the privileges and responsibilities of the chain of custody and use of the MSC logo? The MSC recognized the problem and provided advice to potential clients in 2005:

Where the stock of the certified fishery is shared with other (perhaps uncertified) fisheries, these other activities may deplete the stock and hence have a detrimental impact on the certified fishery. In this situation, the certified fishery risks losing certification because of actions of those outside the certified fishery. The exact choice for the boundaries of the unit of certification can have profound consequences for both the success of the assessment, and the maintenance of the certificate. It is for these reasons that clients are advised to carefully consider the unit of certification, and where feasible, include all sources of extraction from the biological stock of the target species within the fishery to be assessed (Marine Stewardship Council Executive 2005b:2)

Because of the common pool characteristics of most fisheries, a client usually does not have exclusive ownership or access rights to a fish stock. The inability to draw property boundaries through fishery stocks and fleets means that defining who a client or client group is, and to who certification applies at the stock extraction level, is crucial to determine the nature and effects of fisheries certification, including who has the right to have fish products certified and labeled as sustainable (Foley 2012). The key issue is that the impact of all vessels' extractions from the stock, i.e., the 
subtractibility aspect of CPRs, must be included in the unit of certification for the purpose assessing sustainability, but only those vessels' extractions within the applicant client or client group are awarded a right to be certified sustainable and have their products labeled as sustainable. In addition, there is also strong incentive for collective action to secure the support of different groups and interests under a single representative entity. The MSC recommends that client organizations gain the support of various key groups involved in the fishery, including fishermen, processors, government and management agencies, and conservation organizations (MSC 2005). Despite exclusive characteristics of client rights over certificates, clients are nevertheless encouraged to engage in collective action by imposed rules of the MSC's definition of units of certification.

Therefore, MSC certification and eco-labeling create institutions of private property rights and collective action. This can result in exclusionary practices, inclusionary collective action, or both. Much will depend on the specific context and history. Many of the initial fisheries certified were associations of individuals or companies that had worked together collectively and had input into the management process in a process known as comanagement (Kaiser and Edwards-Jones 2006). This led some observers to suggest that the creation of more fishing cooperatives could provide a mechanism for better collective decision making and strategies to make it easier for fisheries to achieve MSC certification. Government intervention would be a "fundamental first step toward developing the underlying structures that will enable currently disparate fishers to modify their behavior appropriately to achieve the requirements for MSC certification" (Kaiser and Edwards-Jones 2006:396-397). However, such a strategy, they cautioned, is more promising in inshore fisheries and in situations in which stocks fall within the jurisdiction of single nation-states (Kaiser and Edwards-Jones 2006). Thus, an important challenge with enrolling producers into technically demanding and costly certification systems is the need to find an institution that can legitimately act on behalf of a local collective interest (Vandergeest 2007), as illustrated by Alaska salmon's two major MSC client transfers (Foley and Hébert 2013). Challenges of representation in certification can be exacerbated and complicated in capture fisheries, because wild fish are mobile resources often accessed by a variety of commercially independent entities that may be in competition over both fish stocks and seafood markets (Eden and Bear 2010, Foley 2012).

Common pool social-ecological systems thus have special implications for MSC governance systems. In some cases, groups have worked together to include the widest range of fishing interests in the client group so as to ensure equitable access. For example, North Sea haddock and nephrops producers formed the Scottish Fisheries Sustainable Accreditation Group (SFSAG) to enter into MSC assessment, with the explicit purpose of extending the unit of certification to cover as much of the Scottish fleet fishing these species as possible (Foley 2012). In other cases, groups representing a portion of extractions have acquired certification to the exclusion of others. For example, white-owned trawler fleets sought certification as a way to prevent the reallocation of quotas to uncertified black-owned smaller-scale South African hake fisheries (Ponte 2008). In still other cases, small-scale and community-based fisheries operating within larger fishery contexts can be disadvantaged by MSC rules, which scale up definitions of sustainability to the entire stock. The certification of the Bering Sea pollock factory trawler fishery was seen by some fishing groups as having serious negative impacts on some communities dependent on local, shore-based, small boat fishing and independent processing operations (Grader et al. 2003). A Brazilian community-based fishery with competent governance capability failed to meet MSC standards because it pursued spiny lobster stocks also pursued by industrial fleets, which had major sustainability and governance problems (Fetherston 2005). The Brazilian case illustrates the issue of having good governance in one component of a system and no control in the other. Given that "one of the most significant issues to consider is whether the holder of the certificate is able to implement (either directly or indirectly) conditions, which may be placed on the fishery client as part of the certification" (MSC 2005:6), small-scale and community-based fishing organizations operating in larger, unhealthier fishery and management contexts may not be well positioned to successfully secure certification on their own.

Governance and collective action problems that disadvantage small-scale and community-based fisheries operating in larger common pool resource situations have emerged internationally as well. During the assessment of a Pacific tuna fishery, the MSC's independent adjudicator ruled that the third-party certification body did not sufficiently identify the Parties to the Nauru Agreement's (PNA) share of the region's skipjack catch, and that the certifier was not justified in concluding that PNA would be capable of managing the entire migratory stock (Scottish Whitefish Producers' Association 2011). In another case, a smallscale fishery pursuing highly migratory Atlantic tuna stocks, the majority of which were extracted by larger fleets, failed MSC assessment after it scored below the required 80 on Principle 1, stock management. The St. Helena pole and line and rod and line tuna fisheries included 12 owner-operators whose catch represented just $1 / 3$ of $1 \%(0.03 \%$ for bigeye, $0.34 \%$ for yellowfin, $0.23 \%$ for albacore, and $0.34 \%$ for skipjack) of the total landings for the Atlantic tuna stocks under the International Commission for the Conservation of Atlantic Tunas (ICCAT) authority (Carleton et al. 2010). Despite seeing clear evidence of intention to reduce harvest if stocks were depleted, the assessors gave a low score because there was no harvest control rule and a lack of evidence that the contracting state parties were able to implement a reduction in total allowable catch (TAC) for Atlantic tuna stocks if/when depleted (Carleton et al. 2010). There was little the client in this case could do to control whole-stock management except encourage ICCAT to implement changes in line with MSC requirements. Although the MSC considers "issues involving allocation of quotas and access to resources... beyond the scope of" its principles and criteria (MSC 2010:4), these issues are unavoidable in many common pool contexts. These situations can result in conflict between different groups, with certified fisheries claiming legitimacy to accessing and managing common pool resources over other fishery participants who they say are not legitimate (Potts et al. 2011).

We now turn to two case studies to further illustrate how and under what conditions MSC certification and eco-labeling can facilitate privatization and collective action. The following case studies are based on interviews and archival studies done in 2005-2010 in Mexico (McCay) and between 2009 and 2012 in Canada (Foley). 


\section{BAJA CALIFORNIA LOBSTER}

The Pacific coast of Mexico provides a notable example of a cooperative-based, small-scale fishery that was able to achieve certification; it was the first small-scale, artisanal fishery to do so. It is a case in which the requirement to scale up the unit of certification to larger social-ecological units could be met by a pre-existing federation of cooperatives, such that the required collective action took place among the cooperatives as well as between them and government agencies, with which they already had important elements of comanagement.

The red rock lobster (Panulirus interruptus) fishery of a group of nine cooperatives on the Pacific coast of Baja California was certified by the MSC in 2004, the first artisanal fishery and first developing nation fishery to be certified as a sustainable and wellmanaged fishery. Its MSC certification was renewed in 2011 when a tenth cooperative was added as well as a distant offshore island (MSC 2011). This case was an early and influential effort to ensure that small-scale and artisanal fisheries could have access to certification, but also underscored the need for outside help in such cases. In 1999, the United States branch of the World Wildlife Fund (WWF-US) together with a local NGO, Comunidad y Biodiversidad (CoBi), initiated a program to use eco-certification as a method of helping small-scale, community-based fisheries receive recognition for, and improve their management of, local fisheries. World Wildlife Fund focused on the Pacifico Norte cooperatives, hoping to help the cooperatives get financial benefits in exchange for their commitment to practices believed to ensure greater sustainability of fisheries (WWF 2008). The process also involved government and university scientists and, of course, the cooperatives themselves, mainly through their regional federation, the Federación Regional de Sociedades Cooperativas de la Industria Pesquera Baja California (FEDECOOP). The high level of investment in such an inclusive, multistakeholder process was an important element in the success of the venture, which had its roots in a longer history of comanagement between the cooperatives, their federation, and officials in the fisheries ministry (Ponce Díaz et al. 2009, McCay et al. 2014).

The geographical area spans Cedros Island, in the state of Baja California to the north, to Punta Abreojos, in the state of Baja California Sur to the south and, added in 2011, Guadalupe Island, located approximately 250 kilometers west of the coast and on the littoral of a vast desert. The fishery is diverse but heavily dependent on benthic crustaceans and shellfish; the fishery for spiny lobster attained MSC certification. Between 2005 and 2010, the average annual catch of spiny lobster from this area was about 1400 metric tons with a value of US\$65 million, representing about $80 \%$ of the national catch. The lobsters are caught in traps, working from small open boats with crews of two to three men. Most of the catch is sold live, but some is also sold whole cooked frozen, whole raw frozen, and frozen lobster tails, almost all exported to Asia. Over 500 fishermen from 10 cooperatives participate in the fishery.

The client for the assessment process was the federation of the cooperatives, a critical source of technical, marketing, and political power. The prior existence and strength of this federation was an important factor in the success of the venture. Its member cooperatives accounted for a large majority of the spiny lobster catch in the region, making it easier to come close to a match between the scope of the client group and of the fish stock. For example, critical to MSC certification is the capacity to manage the fishery (Principle 3). In this relatively data-poor case of fisheries management, meeting that criterion depended heavily on evidence of both long-term sustainability of high levels of catch and catch per unit effort, a very crude indicator of health of the stock, and high levels of management control. The cooperatives' actions are controlled to a large degree by national laws as well as the specific conditions of their concessions, legal factors that provide both constraints and support (McCay et al. 2014). Within this context, the cooperatives take their own resource management initiatives. For example, whereas the federal government establishes the maximum number of lobster traps to be employed in each concession, the cooperatives will decide how to allocate them among members and where to deploy the traps within a concession. The government recognizes boundaries and other rules but to a large extent monitoring and enforcement depends on the cooperatives, which are deputized to monitor boundaries and rule compliance.

A key to the capacity of cooperatives to manage or comanage the fisheries is their exclusive access to CPRs within designated territories, a feature sometimes called territorial use rights for fisheries (TURFs). Today, each of the fishing cooperatives has exclusive access and use rights to abalone, lobster, turban snails, and a few other species within a concession area usually adjacent or close to the fishing settlement. The concessions are roughly $615-4700 \mathrm{~km}^{2}$ each, the median being about $900 \mathrm{~km}^{2}$ (W. L. Vázquez Vera, April 30, 2014, personal communication); they extend $30-50 \mathrm{~km}$ along the coast and at variable distances around the offshore islands (Fig. 1). The concession system has deep roots in Mexican agrarian politics. Exclusive access and use rights for cooperatives began in 1936. In 1992, as part of sweeping changes in Mexico's political economy, the fishery concessions ceased to be perpetual rights of cooperatives; they were also opened to private companies and limited to 20 years, with the prospect of renewal. In such a neo-liberal context, they are closer to private property but the cooperatives, which applied for and were granted their concessions, treat them as common or community property, managing access to the lobster and abalone fisheries for the benefit of members. Having exclusive privileges at the cooperative level provides large incentives for the investments of people, boats, time, and money required to defend the concession CPRs from outsiders (Costello and Kaffine 2008) and to ensure ecological sustainability and social equity in their use by cooperative members (McCay et al. 2014).

Central to the value of the TURF system is the fact that the more valuable resources are benthic invertebrates, for which placebased management makes some sense. The common pool resource problems of nonexclusivity and subtractibility are somewhat lessened by the highly localized natural history of the resource. Lobsters are social, mobile animals that aggregate in rocky areas, generally hiding from larger predators during the day and foraging at night. They show high site fidelity and small home ranges although they can travel ten to hundreds of meters (Stull 1991, Mai and Hovel 2007). The small home ranges for these species also provide a high level of predictability, an ability to monitor stock levels with confidence, and the expectation among fishers that stock conservation will pay off in the future. Therefore, 
Fig. 1. Map of the concessions of the fishery cooperative societies (Sociedades Cooperativas de Producción Pesquera, SCPP) of the Vizcaino region, Baja California and Baja California Sur, Mexico. Courtesy of Leonardo Vázquez, COBI (Comunidad y Biodiversidad), La Paz, Baja California Sur, Mexico.

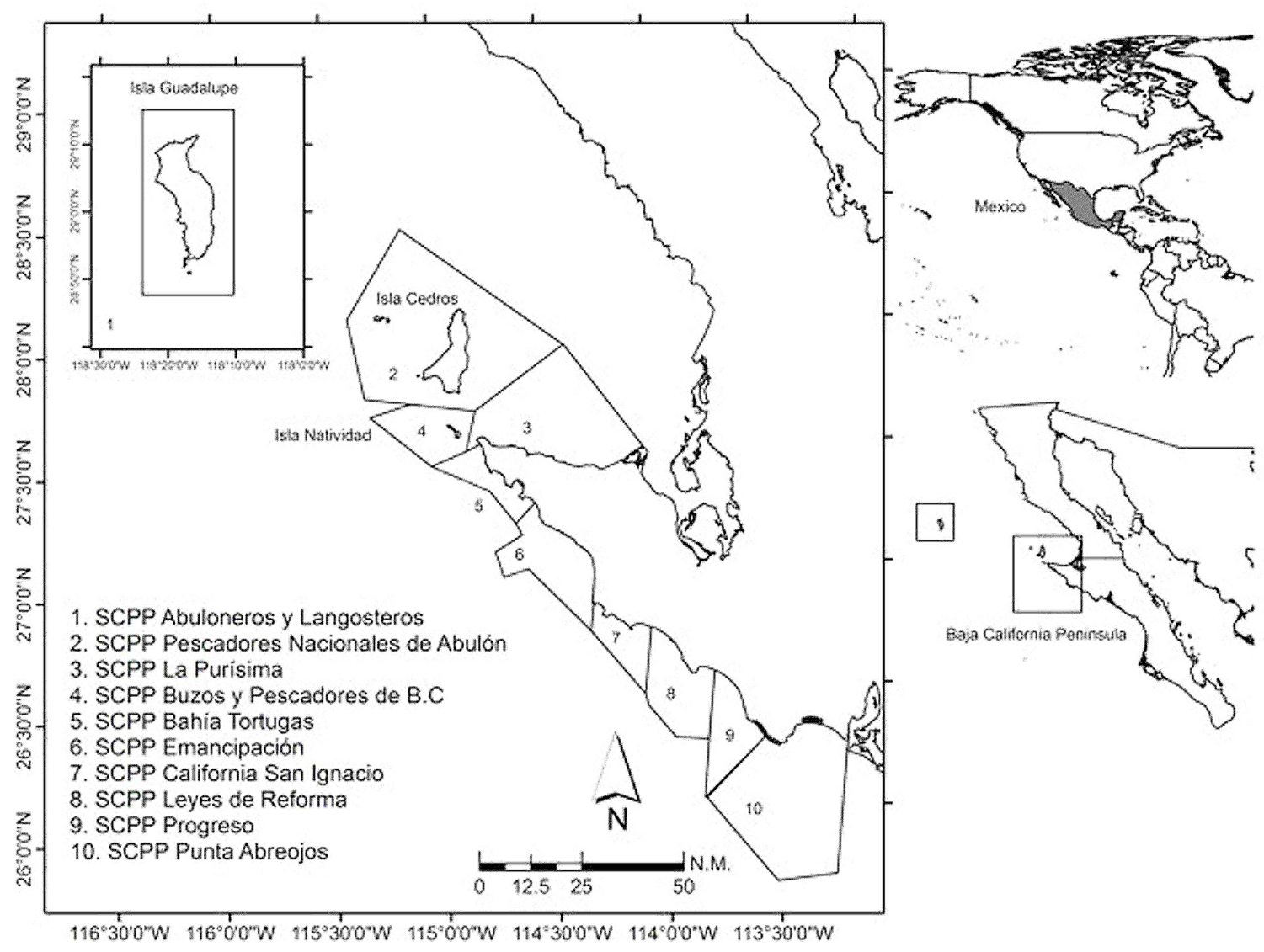

the resources seem to be appropriate for management by smallscale concessions, which may not be the case for less predictable resources and for migratory and far-ranging species (Castilla and Defeo 2001).

However, no one cooperative has a territory large enough to fully bound a lobster population, therefore being part of an enduring and effective federation is critical. In addition to functions such as marketing and politics, the federation carries out joint stock assessment work with the individual technicians of the cooperatives, which plays a role in informing government management decisions. The federation also helps the individual cooperatives coordinate their fisheries, which are side by side along the coast. To the extent that the cooperatives are adjacent to one another on the coast and represent a bloc held together by a sense of common interest, cooperatives have the security of knowing that their neighbors in the bloc at least are 'caring for' lobster and other species in similar ways and preventing incursions of poachers into the overall zone.

One of the reasons given by the World Wildlife Fund and other groups and individuals for taking the trouble to support MSC certification for the Mexican cooperatives is their potential value in providing guidance to other artisanal and coastal fisheries
(MSC 2011). However, the example is not a simple one as numerous factors have influenced the workings of the Baja California lobster fishery and its eligibility for MSC certification. Indeed, their case supports the value of certain 'design principles' for successful small-scale commons management (Ostrom 1990), including smallness of numbers and spatial scale, accountable leadership, persistent efforts to ensure fairness and transparency, major investments in the ability to learn from and interpret the natural environment, and high levels of internal as well as external vigilance (McCay et al. 2011, 2014, Ramirez-Sanchez et al. 2011).

Not to be minimized, though, has been the capacity to reduce common pool problems. The individual cooperatives hold, and are able to enforce, exclusive concessions for lobster fisheries in clearly marked territories off their shores. They deal with the mismatch between concession boundaries and lobster behavior and population structure, i.e., the fact that lobster populations have larger ranges than the concession territories, at least partly by being part of a regional federation, which also addressed the critical coordination problem for MSC by serving as the client for certification. Their remaining CPR problem rests in the diversity of both the marine ecosystem and their fisheries. Being certified for lobster is one thing, and the stewardship incentives and 
paybacks for other species, particularly finfish, is another question. Some of the cooperatives have sizeable finfish fisheries, and one could argue that the management stringency that enables MSC certification for spiny lobster is subsidized by poorly regulated fisheries for other species, an issue that has raised discussion about TURFs, and even certification, for entire placebased ecosystems (Haupt et al. 2013, Micheli et al. 2014).

\section{FOGO ISLAND SHRIMP}

The Northwest Atlantic provides another example of a cooperative-based, small-scale fishery that was able to achieve certification. As will be seen, it is one of privatization through boundary creation, exclusion, and requirements of monetary exchange. It is also a case in which the large-scale mobility and other common pool resource features led to both conflict and cooperation with other groups harvesting the same resource and competing for similar markets.

In August 2008, the Fogo Island Co-operative Society Ltd. was part of a process involving a group of shore-based processing firms in the Canadian province of Newfoundland and Labrador (NL), which obtained MSC certification for Northern shrimp (Pandalus borealis), the first aquatic species managed by the Canadian government to meet the MSC's environmental standard and, at the time, the largest cold water shrimp fishery to attain MSC certification. However, the Fogo Island Co-op lost access to MSC certification in 2010 when its membership in the processing association, which had been acting as MSC client, was terminated. The cooperative then acquired its own MSC certification via a separate process in 2011, and then in 2012 withdrew its certification to share access to a separate certification initiative that encompassed the same Northern shrimp resource.

Growing retailer demands for MSC-certified products in the UK and Europe in the 2000s stimulated Newfoundland and Labrador fish processors' interest in MSC certification. In 2006, the Association of Seafood Producers (ASP), representing owners of 7 of the 12 shrimp processing plants, which then operated in Newfoundland and Labrador's inshore sector, applied as client for MSC certification for the inshore portion of the Northern shrimp fishery located in shrimp fishing areas (SFAs) 5-7. Fogo Island is located about 14 kilometers off the northeast coast of Newfoundland adjacent to SFA 6 (Fig. 2). Recently amalgamated as 1 municipality, it consists of 11 geographically distinct community settlements with a total population of about 2500 . The Fogo Island Co-op was a member of ASP, which successfully acquired MSC certification in August 2008, giving the Co-op and businesses that purchased its shrimp, the right to sell shrimp as sustainable by MSC standards.

Members of the Fogo Island Co-op extract a relatively small portion of certified shrimp from SFA 5-7. Its fishers regularly trawl for shrimp in view of much larger offshore factory freezer trawlers, as well as inshore owner-operator fishers who operate out of ports along the Newfoundland and Labrador coasts. About a dozen Fogo Island Co-op vessels with shrimp quotas were among the more than 300 inshore owner-operator enterprises listed in MSC assessment documents, but shrimp from these vessels could only become eligible to bear the MSC eco-label in the market if sold through an ASP member's processing plant, which held the chain of custody certification. Notably, the client group did not include a separate offshore factor freezer fleet of about a dozen vessels, which caught shrimp in the same ocean areas, nor did it include five inshore shrimp processing plants that were not members of ASP. Upon learning that the shrimp they acquired from certified areas could not be sold by them or buyers with the MSC eco-label, because they did not have a chain of custody certification and could not acquire one without permission from the client that held the main MSC certificate (ASP), processors and fishers who sold to them questioned the legitimacy of the certification process. Following a prolonged dispute in which processors outside the client group claimed that the certification was in disrepute, ASP agreed to share access to its certification on the condition that processors join the organization and contribute financially to past and future certification costs. This episode highlighted the issue of certificate exclusivity and sharing and demonstrated how apparent ownership and access rights can emerge under MSC certification in common pool contexts.

Fig. 2. Fogo Island and Department of Fisheries and Oceans (DFO) Shrimp Fishing Areas (SFAs).

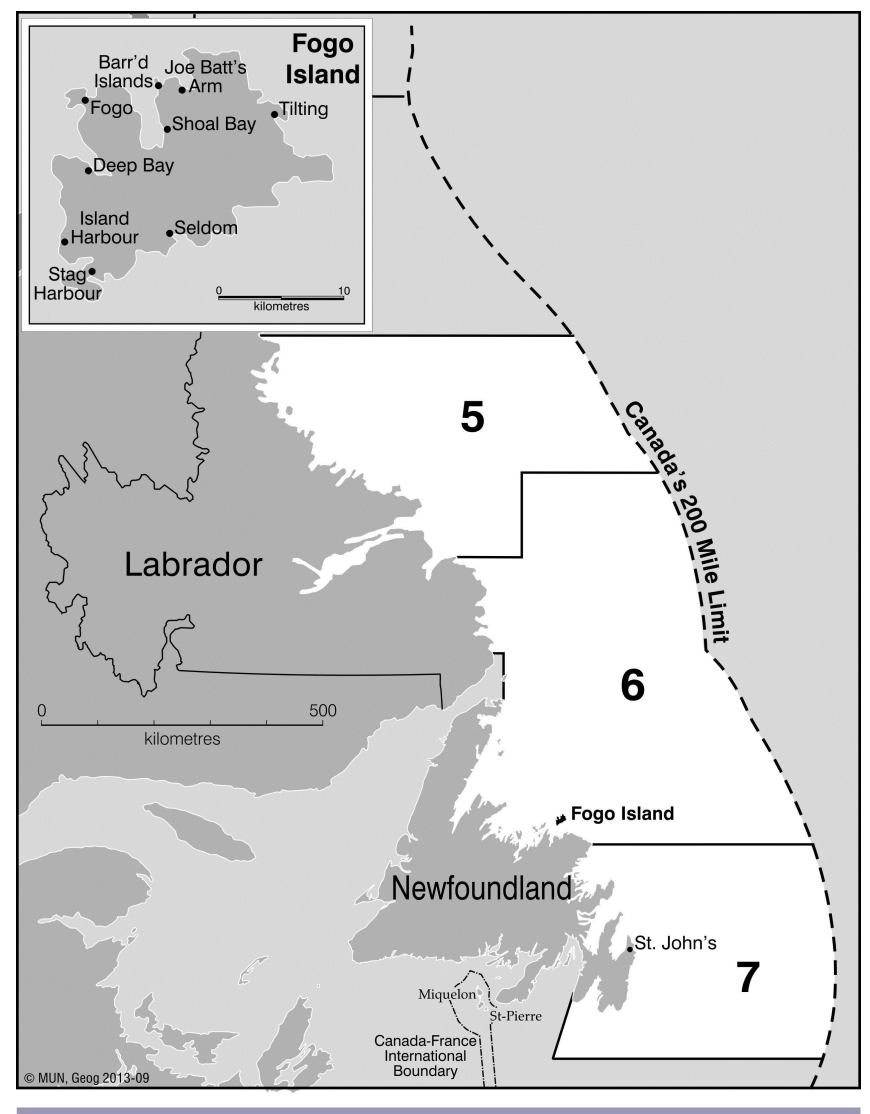

That was 2008. In the 2009 fishing season, certificate holder privileges resulted in a different outcome, when the ASP expelled the Fogo Island Co-op from its membership after the Co-op broke rank with the affiliated processing association during a collective bargaining dispute with the Fish Food and Allied Workers (FFAW) union over then uncertified crab prices. By implication, this expelled the Co-op from the nominal MSC client group. The Co-op had been unaware that it could lose access to MSC 
certification, having contributed financially to the existing certification and having a chain of custody certificate document in its possession. Most significantly, losing access to MSC certification jeopardized the Co-op's ability to sell its shrimp in the European market (Penton 2010), because international buyers would no longer be able to use the MSC eco-label on shrimp purchased from the Co-op. Accordingly, buyers who had been purchasing the Co-op's shrimp began considering ending those purchases and replacing them with certified sources from other producers. Meanwhile, the Co-op took legal advice on its rights to MSC certification and explored how it could regain the right to have its shrimp products MSC-certified and labeled. The Coop then decided to embark in its own right on the costly certification process needed for acquiring and maintaining its own MSC certification, no doubt partly assured of a successful outcome because the Northern shrimp fishery already met the MSC's environmental standard for sustainable fishing. The MSC announced that the Co-op had contracted Global Trust Certification Ltd. to assess the Northern shrimp fishery, beginning the assessment in September 2010 and ending with successful certification in October 2011.

Just prior to the start of the new MSC assessment for Northern shrimp initiated by the Fogo Island Co-op, the Canadian Association of Prawn Producers (CAPP) and the Northern Coalition applied for MSC assessment for offshore factory freezers that operated in SFAs 1-7, which included areas in which both the ASP members and Fogo Island Co-op acquired shrimp. The multiple overlapping certifications developing within Canada's Northern shrimp fishery created financial and human resource redundancy costs for the Canadian federal agency responsible for marine fisheries, the Department of Fisheries and Oceans (DFO), whose participation in the process is necessary, substantial, and ongoing (Foley 2013). To create greater efficiency and cost savings for clients and for the government management agency, as well as to create more harmonized and cooperative conditions for recertification efforts, the three different MSC clients agreed to a new certificate-sharing arrangement in 2012 with the amalgamation of three separate certifications for the Northern shrimp fishery in SFAs 5, 6, and 7. The ASP and Fogo Island Co-op certifications were withdrawn. Notably, the new shared certification does not include the word 'offshore,' and the new fishery is called "Canada Northern Shrimp Trawl Fishery SFA 5, 6 \& SFA 7," which obscures social, technological, regulatory, and public policy differences between the factory freezer trawler fleet and the under 65 feet owner-operator trawler fleet.

Various ecological, geographic, social, and political factors conditioned the Fogo Island Co-op's experience with MSC certification. Northern shrimp are crustaceans usually found in waters with temperatures between about 1-6 degrees Celsius and in areas with a soft, muddy ocean floor at depths between 150-600 meters. More importantly, Northern shrimp is a circumpolar shellfish with southern physiological and ecological limits in the Gulf of Maine and is most abundant north from $46^{\circ} \mathrm{N}$, off Nova Scotia, to $75^{\circ} \mathrm{N}$, off Baffin Island (Koeller 2000, Koeller et al. 2007, DFO 2009). The initial shrimp fishery in the study area developed through a period of 'Canadianization' from 1977-1991, when the Canadian government allocated 17 licenses to East Coast interests to develop an offshore factory freezer trawler fleet, which operated mainly in northerly areas off Labrador and Baffin Island (Parsons and Fréchette 1989; M. Allain, unpublished manuscript).

Transformations in both the biological regime of Northern shrimp and the resource access policies for Northern shrimp coincided with the cod collapse of the late twentieth century. By the mid-1990s, scientists were observing a significant growth, and perhaps migration/movement south, in the biomass of Northern shrimp in areas off the northeast coast of Newfoundland and Labrador. The biological regime change was influenced by both the decline in cod populations, one of Northern shrimp's main predators, and cooling ocean temperatures, though the relative importance of these and other environmental factors remains unclear (Lilly et al. 2000, Worm and Myers 2003). With successive extensions of the initial cod moratorium and additional new closures in the 1990s, the Fogo Island Co-op, like Atlantic Canada's fishing industries more generally, increasingly turned their efforts toward internationally lucrative shellfish, such as snow crab and shrimp. In addition to increasing quotas for the existing offshore fleet, which had engaged in shrimp trawling since the late 1970s, the Government of Canada allocated more than 300 shrimp permits to inshore fishers in Newfoundland and Labrador and distributed a series of special allocations to various community groups for economic development purposes. The expanded catches helped Canada become the world's largest producer of Northern shrimp in the 2000s and meant that shrimp was consistently Canada's leading seafood export by volume in the late 2000 s, with total annual catches peaking at 185,974 tons in 2007, up from the 37,600 tons allocated evenly among offshore licenses in 1996 (DFO 2007, 2008, 2009, 2010, 2011).

A key feature in this situation is the ability of harvesters and processors to gain access to and benefit from shrimp resources adjacent to its shores during the late 1990s. For the Fogo Island Co-op, its entry into the shrimp fishery followed a long history of diversification and development strategy. In the late 1960s, in response to the pullout of private fish merchants from the island and a looming federal-provincial resettlement program encouraging residents to permanently move off the island, residents from different communities came together to form the Fogo Island Co-operative Society Limited. The Co-op, which is currently jointly owned by fish harvesters, processing plant workers, and management personnel, has been the anchor of Fogo Island's economic development since it was formed and currently has a fleet of about 30 nearshore vessels, longliners ranging from about 30 to over 65 feet in length, and three fish processing plants. The island's fisheries had long been dominated by cod and the Co-op played a major role in fisheries' diversification in the $1980 \mathrm{~s}$ and 1990s, initially based mostly on snow crab, and more recently on shrimp, along with other minor fisheries (McCay 1999). About 10 of the Co-op's member harvesters in the small boat, inshore owner-operator fleet joined several hundred other owneroperators in gearing their vessels up for shrimp trawling. The new catch posed a problem for the Co-op, however, because it did not have facilities to process the shrimp. Concerned that it would lose fisher-members and, consequently, lose access to large suppliers of crab for its crab processing plant if other processors demanded access to their other species as a condition of processing shrimp, the Co-op successfully lobbied the Government of Newfoundland and Labrador, which has jurisdiction over the processing 
licensing, for a shrimp processing license and partnered with two Icelandic firms in 2000 to build a shrimp processing plant in the community of Seldom. The Co-op also successfully lobbied the Government of Canada for a special allocation of shrimp, which it contracted out to offshore factory freezer vessels to generate capital, which helped secure shrimp processing facilities for its inshore fishers. The Co-op bought out the Icelandic firms' stake in the shrimp operation in the mid-2000s and successfully marketed most of its cooked and peeled shrimp in Europe and, to a lesser extent, in the U.S. (Penton 2010).

A key feature shaping the certification dynamics in this case is the diversity of resource access patterns and industry cleavages, which in turn have been shaped by past policy and political economy. The offshore shrimp vessels, which initially developed the Northern shrimp fishery in the 1970s and 1980s, are governed by federal offshore licensing frameworks and operate under an enterprise allocation system, with quotas transferable only within current season to other license holders (Barrow et al. 2001). The offshore sector is permitted to catch shrimp year round. The Fogo Island Co-op is embedded in larger social-ecological fishery contexts, and its capacity to govern is limited by a specific common pool situation. The inshore sector, in which the Fogo Island Coop primarily operates, is governed by federal owner-operator and fleet separation policies. Shrimp quotas in the inshore sector are limited to vessels between 45 and 65 feet in length and the inshore shrimp fishery is limited from spring to early fall, with most activity occurring in July and August. The initial certification of Northern shrimp was led by processors in the inshore sector. It therefore did not include all social extractions from the stock. This was followed by episodes of conflict, multiplication of overlapping certifications, and finally cooperation, which resulted in a single consolidated certification for Northern shrimp.

\section{DISCUSSION}

Certification and eco-labeling programs like those administered by the MSC are privatized governance tools that when implemented and acquired in particular fisheries and places, embed new social relations and institutions in existing socialecological systems, including contexts of threatened fisheries and coastal communities. Their relevance to, and implications for, community-oriented and small-scale fisheries are problematic. As noted above, the MSC does not include explicit social and community-oriented principles, criteria and indicators in its standard of sustainability. Unlike fair trade programs, it does not contain institutional mechanisms designed explicitly to guarantee tangible material welfare benefits to producers (Goyert et al. 2010, Perez-Ramirez et al. 2012). Incorporating social and communityoriented principles and indicators into the MSC's core standard will likely be challenging, given the institutional inertia of the existing standard, reluctance to deal with the greater complexity such changes will inevitably entail (Parkes et al. 2010), the multidimensional challenges of developing 'appropriate' common social indicators outside broader institutional contexts (Bacon et al. 2012), and the broader issues of who is responsible for enforcing certification criteria (Tejeda-Cruz et al. 2010).

The case study analyses of fisheries cooperatives in Mexico and Canada produce notable insights about the interaction between privatized certification and eco-labeling institutions and common pool social-ecological systems. Both cases involve cooperatives, place-based communities, and an important historical and continuing role of the state, but differences in both the ecology of marine animals targeted and the heritage of experience, resource access rights, industry structures, and governance systems involved produced quite different relationships among private certification and eco-labels, common pool resources, and community-based fisheries in each case. The Baja California lobster fishery, with relatively stationary populations close to Mexico's coasts, was more amenable to small-scale concessions and community-based management systems. The exclusive territorial rights system in this fishery and the institutional unity of fishers under the federation of cooperatives enhanced the capacity of this small-scale fishery to manage coordination problems both in the fishery and in the MSC certification process. Strong cooperatives with clearly defined resource access rights were important factors, which contributed to the co-op's ability to govern and achieve sustainability certification. It also depended on support from the WWF, other NGOs, the government, and external researchers.

By contrast, the Northern shrimp fishery of Canada involved a mobile resource with an extensive geographic range, different fleets extracting and sharing resources in the same areas, and different resource access regimes governing the fishery. This common pool resource was far less amenable to local, communitybased institutions of management and the scale problem required large coalitions of seafood enterprises to enter into MSC assessment. The Fogo Island Co-op's experience highlighted the general common pool resource problem of coordinating the complex dynamics that occur when socioeconomic and ecological unit scales are discordant. Multiple overlapping certifications emerged in a context of divided sectors and conflicting interests. No obvious industry institution existed to represent the common interests of the shrimp fishery, aside perhaps from DFO, which encouraged the separate clients to consolidate and harmonize their redundant certifications. The Fogo Island Co-op's participation in three separate certification processes for the same resource also illustrates how 'ownership,' control and possession of MSC certificates confers powers of access, exclusion, and privileges resembling property rights, as well as showing how conflicts and cooperation can result from the injection of private certification in certain common pool contexts.

In this respect, two key findings with broader implications are worth emphasizing. First, certification and eco-labeling confer rights and responsibilities on certificate holders. The MSC certification introduces another form of privatized property rights into situations that are already burdened by multiple, and sometimes overlapping, forms of property rights and resource access privileges. Certification and licensing confers a property right to the use of a label, which can open access to market and increase values (Guthman 2007) in certain situations, effectively constituting a license to market. The injection of new privatized property rights into already existing commodity relations and into common pool resource situations also creates conditions for confusion and conflict, as well as cooperation. Notably, although the property rights of certificates and eco-labels create value, they are not fully transferable or tradable, i.e., marketable. Certification holders can, however, offer membership in the client group to others for a fee. Nor are they fungible or capable of being divided up, though the Northern shrimp and Fogo Island case of 
possessing and dispossessing access rights to certification and labels may challenge this characteristic. The MSC certification, held formally by clients, also resembles common property in that various interests within client groups can gain and share the right to be designated MSC-certified and the right for their products to bear the MSC's trademarked eco-label.

Second, a critical implication of the MSC's whole stock definition of sustainability is that certification must encompass socially expansive realities of resource extraction and sharing in many common pool situations. For these reasons, MSC rules encourage collective action and support among all groups that extract from the target stock, yet organizations embedded in larger fisheries can still seek to acquire certification on their own and to the exclusion of others. Social representation and equity issues can arise when ecological systems of production and social systems of production are not matched up under a client group. Although both community-based fisheries examined above were operating under relatively healthy fishery management regimes, small-scale and community-based fishing organizations operating in larger, less robust fishery and management contexts may not be well positioned to successfully secure certification on their own given that certificate holders are expected to be able to implement conditions that may be placed on the fishery client as part of the certification.

In summary, MSC certification and eco-labeling can facilitate patterns of privatization, individualization, comanagement, and collective action, simultaneously and at various points over time. We analyzed multiple and overlapping institutions of property rights, resource access, and privatization in common pool situations. The analysis shows how both property rights and privatization are highly variable. The MSC certificates can be both private property and common property, with potential for exclusion and shared access. Even more broadly, environmental certification reveals complexities around the understanding of what a fishery is. A fishery can be defined in different ways for the purposes of certification, depending on social-ecological characteristics of marine animals, ecosystems, peoples and institutions of collective action, governance, and trade at various scales and levels.

\section{CONCLUSION}

Fisheries governance is privatized through MSC environmental certification and labeling processes. The MSC certification and labeling is not 'just' privatization, however. As a charity, the MSC has a mandate to serve the public interest. It also promotes a number of multistakeholder and participatory processes in its own governance structure and in its certification methodology. Overall, the key point is that the MSC promotes relatively open, inclusive, and collaborative processes, but those processes are shaped by the interaction between privatized institutions and the social-ecological characteristics of fisheries. On the one hand, certification and eco-labeling systems like the MSC privatize environmental governance, not only because rules and standards are administered by nonstate/nongovernmental organizations, and compliance is oriented toward incentivizing change in the market, but also through the creation of altogether new property rights to certificates and eco-labels at the level of implementation and uptake. This additional institutional and legal layer of privatization creates conditions for both exclusionary and inclusionary practices with the determination of clients/client groups and units of certification.

On the other hand, MSC's rules defining units of certification and fishery sustainability promotes coordination and collective action at a scaled up social-ecological level encompassing all social extractions from targeted stocks. For this reason, social and power relations and institutions that organize resource access, property, and ownership in resource systems (Ribot and Peluso 2003, Mansfield 2007, Sikor and Lund 2009, Campling et al. 2012, De Alessi 2012, Havice and Reed 2012), as well as processing, marketing, and trade issues across multiple scales, are important to the understanding of the implementation and effects of certification and eco-labeling in particular contexts. These relations and institutions proved significant in shaping the different certification experiences of the Mexican and Canadian cooperatives. However, collective action challenges of bargaining and coalition building will remain for fisheries that need to make significant changes to meet the MSC's environmental standard and further research is required to examine the extent to which MSC certification can provide a strong enough incentive to engage in collective action. Although both cases examined were determined to be sustainable fisheries overall, the whole-stock approach will make it difficult for similar small-scale and community-based fisheries to successfully attain certification if they are part of larger unhealthy fishery systems in which the participants engaging in the bulk of extraction are uninterested in making the necessary changes for MSC certification. For some small-scale and community-based fisheries, this will be a tragedy of certification.

\section{Responses to this article can be read online at: http://www.ecologyandsociety.org/issues/responses. $\mathrm{php} / 6459$}

\begin{abstract}
Acknowledgments:
Support for the Mexican case study came from the U.S. National Science Foundation program, Biocomplexity in the Environment (OCE-0410439), with thanks to coprincipal investigators and assistants in the project and members of the fishing cooperatives and their federation, which was a partner. Support for the Canadian case came from the Ontario Graduate Scholarship (OGS) program, the Social Sciences and Humanities Research Council of Canada (SSHRC) funded Privatizing Environmental Governance research project, the Natural Sciences and Engineering Research Council of Canada (NSERC) funded Canadian Fisheries Research Network project, and the Leslie Harris Centre for Regional Policy and Development's Applied Research Fund at Memorial University.
\end{abstract}

\section{LITERATURE CITED}

Bacon, C. M., C. Getz, S. Kraus, M. Montenegro, and K. Holland. 2012. The social dimensions of sustainability and change in diversified farming systems. Ecology and Society 17(4): 41. http:// dx.doi.org/10.5751/ES-05226-170441

Barrow, J., G. E. Jefferson, M. D. Eagles, and G. J. Stevens. 2001. Allocation of harvesting rights in three Atlantic Canada marine 
fisheries. Pages 32-57 in R. Shotton, editor. Case studies on the allocation of transferable quota rights in fisheries. FAO fisheries technical paper-411. Food and Agriculture Organization, Rome, Italy. [online] URL: http://www.fao.org/docrep/005/y2684e/ y2684e06.htm\#P0 0

Campling, L., E. Havice, and P. McCall Howard. 2012. The political economy and ecology of capture fisheries: market dynamics, resource access and relations of exploitation and resistance. Journal of Agrarian Change 12(2-3):177-203. http://dx. doi.org/10.1111/j.1471-0366.2011.00356.X

Carleton, C., P. Medley, T. Southhall, and M. Gill. 2010. MSC sustainable fisheries certification: St Helena pole \& line and rod \& line tuna fisheries for albacore, bigeye, yellowfin and skipjack tuna: public certification report. Marine Stewardship Council, London, UK. [online] URL: http://www.msc.org/track-a-fishery/fisheriesin-the-program/exiting-the-program/not-certified/st-helena-poleand-line-rod-and-line-tuna/assessment-downloads

Cashore, B. 2002. Legitimacy and the privatization of environmental governance: how non-state market-driven (NSMD) governance systems gain rule-making authority. Governance 15(4):503-529. http://dx.doi.org/10.1111/1468-0491.00199

Castilla, J. C., and O. Defeo. 2001. Latin American benthic shellfisheries: emphasis on co-management and experimental practices. Reviews in Fish Biology and Fisheries 11:1-30. http://dx. doi.org/10.1023/A:1014235924952

Costello, C. J., and D. Kaffine. 2008. Natural resource use with limited-tenure property rights. Journal of Environmental Economics and Management 55:20-36. http://dx.doi.org/10.1016/ j.jeem.2007.09.001

De Alessi, M. 2012. The political economy of fishing rights and claims: the Maori experience in New Zealand. Journal of Agrarian Change 12(2-3):390-412. http://dx.doi.org/10.1111/j.1471-0366.2011.00346. $\underline{x}$

Department of Fisheries and Oceans (DFO). 2007. Integrated fisheries management plan: northern shrimp-shrimp fishing areas (SFAs) 0-7 and the Flemish Cap. Department of Fisheries and Oceans, Resource Management Operations, Atlantic, Ottawa, Ontario, Canada. [online] URL: http://www.dfo-mpo.gc.ca/fmgp/peches-fisheries/ifmp-gmp/shrimp-crevette/shrimp-crevette-2007eng.htm

Department of Fisheries and Oceans (DFO). 2008. Canada's fisheries fast facts 2008. Fisheries and Oceans Canada, Statistical Services: Economic Analysis and Statistics Strategic Policy Sector, Ottawa, Ontario, Canada. [online] URL: http://www.dfompo.gc.ca/stats/facts-Info-eng.htm

Department of Fisheries and Oceans (DFO). 2009. Canada's fisheries fast facts 2009. Fisheries and Oceans Canada, Statistical Services: Economic Analysis and Statistics Strategic Policy Sector, Ottawa, Ontario, Canada. [online] URL: http://www.dfompo.gc.ca/stats/facts-Info-09-eng.htm

Department of Fisheries and Oceans (DFO). 2010. Canada's fisheries fast facts 2010. Fisheries and Oceans Canada, Statistical Services: Economic Analysis and Statistics Strategic Policy Sector, Ottawa, Ontario, Canada. [online] URL: http://www.dfompo.gc.ca/stats/facts-Info-10-eng.htm
Department of Fisheries and Oceans (DFO). 2011. Shrimp. Fisheries and Oceans Canada, Ottawa, Ontario, Canada. [online] URL: http://www.dfo-mpo.gc.ca/fm-gp/sustainable-durable/fisheriespeches/shrimp-crevette-eng.htm

Ecotrust. 2011. Community dimensions of fisheries catch share programs: integrating economy, equity, and environment. Ecotrust and National Panel on the Community Dimensions of Fisheries Catch Share Programs, Vancouver, British Columbia, Canada. [online] URL: http://www.ecotrust.org/media/NPCDFCSP_paper_031511. pdf

Eden, S., and C. Bear. 2010. Third-sector global environmental governance, space and science: comparing fishery and forestry certification. Journal of Environmental Policy and Planning 12 (1):83-106. http://dx.doi.org/10.1080/15239081003626000

Feeny, D., F. Berkes, B. J. McCay, and J. M. Acheson. 1990. The tragedy of the commons: twenty-two years later. Human Ecology 18(1):1-19. http://dx.doi.org/10.1007/BF00889070

Fetherston, E. H. 2005. Sustainability certification in communitybased fisheries. Thesis. Duke University, Durham, North Carolina, USA. [online] URL: dukespace.lib.duke.edu/dspace/ handle/10161/226

Scottish White Fish Producers' Association. 2011. Adjudicator raises concerns over MSC certification of Pacific tuna fishery. FishEUnews.com Scottish White Fish Producers' Association, Fraserburgh, Scotland. [online] URL: http://www.fishnewseu. com/index . phpoption $=$ com content $\&$ view $=$ article $\& i d=7165$ : adjudicatorraises-concerns-over-msc-certification-of-pacific-tuna-fishery\&catid $=46$ : world \&Itemid $=56$

Foley, P. 2012. The political economy of Marine Stewardship Council certification: processors and access in Newfoundland and Labrador's inshore shrimp industry. Journal of Agrarian Change 12(2-3):436-457. http://dx.doi.org/10.1111/j.1471-0366.2011.00344. $\underline{\mathrm{X}}$

Foley, P. 2013. National government responses to Marine Stewardship Council (MSC) certification: insights from Atlantic Canada. New Political Economy 18(2):284-307. http://dx.doi. org/10.1080/13563467.2012.684212

Foley, P., and K. Hébert. 2013. Alternative regimes of transnational environmental certification: governance, marketization, and place in Alaska's salmon fisheries. Environment and Planning 45(11):2734-2751. http://dx.doi.org/10.1068/a45202

Goyert, W., R. Sagarin, and J. Annala. 2010. The promise and pitfalls of Marine Stewardship Council certification: Maine lobster as a case study. Marine Policy 34(5):1103-1109. http://dx. doi.org/10.1016/j.marpol.2010.03.010

Grader, Z., P. Parravano, G. Spain, and N. Benjamin. 2003. Going beyond fish eco-labeling: is it time for fair trade certification too? Fishermen's News March 2003. Pacific coast federation of fisherman's associations, San Francisco, California, USA. [online] URL: http://www.pcffa.org/fn-mar03.htm

Guthman, J. 2004. Agrarian dreams: the paradox of organic farming in California. University of California Press, Oakland, California, USA. 
Guthman, J. 2007. The Polanyian way? Voluntary food labels as neoliberal governance. Antipode 39(3):456-478. http://dx.doi. org/10.1111/j.1467-8330.2007.00535.X

Haupt, A. J., F. Micheli, and S. R. Palumbi. 2013. Dispersal at a snail's pace: historical processes affect contemporary genetic structure in the exploited wavy top snail (Megastraea undosa). Journal of Heredity 104:327-340. http://dx.doi.org/10.1093/ jhered/est002

Havice, E., and K. Reed. 2012. Fishing for development? Tuna resource access and industrial change in Papua New Guinea. Journal of Agrarian Change 12(2-3):413-435. http://dx.doi. org/10.1111/j.1471-0366.2011.00351.x

Kaiser, M. J., and G. Edwards-Jones. 2006. The role of ecolabeling in fisheries management and conservation. Conservation Biology 20(2):392-398. http://dx.doi.org/10.1111/j.1523-1739.2006.00319. $\underline{\mathrm{x}}$

Kalfagianni, A., and P. Pattberg. 2013. Fishing in muddy waters: exploring the conditions for effective governance of fisheries and aquaculture. Marine Policy 38:124-132. http://dx.doi.org/10.1016/ j.marpol.2012.05.028

Koeller, P. A. 2000. Relative importance of abiotic and biotic factors to the management of the northern shrimp (Pandalus borealis) fishery on the Scotian shelf. Journal of Northwest Atlantic Fishery Science 27:21-33. http://dx.doi.org/10.2960/J.v27.a3

Koeller, P. A., C. Fuentes-Yaco, and T. Platt. 2007. Decreasing shrimp (Pandalus borealis) sizes off Newfoundland and Labrador - environment or fishing? Fisheries Oceanography 16(2):105-115. http://dx.doi.org/10.1111/j.1365-2419.2006.00403.x

Lilly, G. R., D. G. Parsons, and D. W. Kulka. 2000. Was the increase in shrimp biomass on the northeast Newfoundland shelf a consequence of release in predation pressure from cod? Journal of Northwest Atlantic Fishery Science 27:45-61. http://dx.doi. org/10.2960/J.v27.a5

Mai, T. T., and K. A. Hovel. 2007. Influence of local-scale and landscape-scale habitat characteristics on California spiny lobster (Panulirus interruptus) abundance and survival. Marine and Freshwater Research 58:419-428. http://dx.doi.org/10.1071/ MF06141

Mansfield, B. 2007. Property, markets, and dispossession: the Western Alaska community development quota as neoliberalism, social justice, both, and neither. Antipode 39(3):479-499. http:// dx.doi.org/10.1111/j.1467-8330.2007.00536.x

Marine Stewardship Council Executive. 2005b. Guidance to clients: the MSC fishery assessment and certification process. Information sheet 3 - the unit of certification explained. Marine Stewardship Council, London, UK. [online] URL: http://www. scscertified.com/fff/docs/Public InfoSheet3UnitOfCertification100606. pdf

Marine Stewardship Council Executive. 2005a. Guidance to clients: the MSC fishery assessment and certification process. Information sheet 5 - roles and responsibilities explained. Marine Stewardship Council, London, UK. [online] URL: http://www. scscertified.com/docs/Public InfoSheet5Roles\&Responsibilities.pdf

Marine Stewardship Council (MSC). 2005. Guidance to potential or actual clients: the MSC fishery assessment and certification process. Version 1, 4 October 2005. Marine Stewardship Council, London, UK. [online] URL: http://www.caaaq.gouv.qc.ca/ userfiles/File/Memoires $\% 20$ lecture $\% 20$ seule/11-Quebec solidaire Annexe4.pdf

Marine Stewardship Council (MSC). 2010. MSC fishery standard principles and criteria for sustainable fishing. Version 1.1, 1 May 2010. Marine Stewardship Council, London, UK > [online] URL: http://www.msc.org/documents/scheme-documents/msc-standards/ MSC environmental standard for sustainable fishing.pdf

Marine Stewardship Council (MSC). 2011. Baja California red rock lobster fishery receives MSC re-certification for expanded area. Marine Stewardship Council, London, UK.

McCay, B. J. 1999. "That's not right": resistance to enclosure in a Newfoundland crab fishery. Pages 301-320 in D. Newell and R. E. Ommer, editors. Fishing places, fishing people: traditions and issues in Canadian small-scale fisheries. University of Toronto Press, Toronto, Ontario, Canada.

McCay, B. J. 2000. Property rights, the commons, and natural resource management. Pages 67-82 in M. D. Kaplowitz, editor. Property rights, economics, and the environment. JAI Press, Greenwich, Connecticut, USA.

McCay, B. J. 2004. ITQs and community: an essay on environmental governance. Agriculture and Resource Economics Review 33(2):162-170. [online] URL: http://purl.umn.edu/31265

McCay, B. J., F. Micheli, G. Ponce-Díaz, G. Murray, G. Shester, S. Ramirez-Sanchez, and W. Weisman. 2014. Cooperatives, concessions, and co-management on the Pacific coast of Mexico. Marine Policy 44:49-59. http://dx.doi.org/10.1016/j.marpol.2013.08.001

McCay, B. J., W. Weisman, and C. F. Creed. 2011. Coping with environmental change: systemic responses and the roles of property and community in three fisheries. Pages 381-400 in R. E. Ommer, R. I. Perry, P. Cury, and K. Cochrane, editors. World fisheries: a social-ecological analysis. Wiley-Blackwell, Oxford, $\mathrm{UK}$.

Micheli, F., G. De Leo, G. G. Shester, R. L. G. Martone, S. E. Lluch-Cota, C. Butner, L. B. Crowder, R. Fujita, S. Gelcich, M. Jain, S. E. Lester, B. J. McCay, R. Pelc, and A. Sáenz-Arroyo. 2014. A system-wide approach to supporting improvement in seafood production practices and outcomes. Frontiers in Ecology and the Environment, in press.

Moloney, D. G., and P. H. Pearse. 1979. Quantitative rights as an instrument for regulating commercial fisheries. Journal of the Fisheries Research Board of Canada 36:859-866. http://dx.doi. org/10.1139/f79-124

Ostrom, E. 1990. Governing the commons: the evolution of institutions for collective action. Cambridge University Press, Cambridge, UK. http://dx.doi.org/10.1017/CBO9780511807763

Parkes, G., J. A. Young, S. F. Walmsley, R. Abel, J. Harman, P. Horvat, A. Lem, A. MacFarlane, M. Mens, and C. Nolan. 2010. Behind the signs - a global review of fish sustainability information schemes. Review in Fisheries Science 18(4):344-356. http://dx.doi.org/10.1080/10641262.2010.516374

Parsons, D. G., and J. Fréchette. 1989. Fisheries for northern shrimp (Pandalus borealis) in the Northwest Atlantic from Greenland to the Gulf of Maine. Pages 63-85 in J. F. Caddy, editor. 
Marine invertebrate fisheries: their assessment and management. John Wiley and Sons, Hoboken, New Jersey, USA.

Penton, C. 2010. Crab, crab and more crab. Fogo Island Flame 6 (3):15-16.

Perez-Ramírez, M., B. Phillips, D. Lluch-Belda, and S. LluchCota. 2012. Perspectives for implementing fisheries certification in developing countries. Marine Policy 36(1):297-302. http://dx. doi.org/10.1016/j.marpol.2011.06.013

Ponce Díaz, G., W. Weisman, and B. J. McCay. 2009. Coresponsabilidad y participación en el manejo de pesquerías en México: lecciones de Baja California Sur. Pesca y Conservación 1:14-22.

Ponte, S. 2008. Greener than thou: the political economy of fish ecolabeling and its local manifestations in South Africa. World Development 36(1):159-175. http://dx.doi.org/10.1016/j. worlddev.2007.02.014

Ponte, S. 2012. The Marine Stewardship Council (MSC) and the making of a market for 'sustainable fish.' Journal of Agrarian Change 12(2-3):300-315. http://dx.doi.org/10.1111/j.1471-0366.2011.00345. $\underline{\mathrm{x}}$

Potts, T., R. Brennan, C. Pita, and G. Lowrie. 2011. Sustainable seafood and eco-labelling: the Marine Stewardship Council, UK consumers, and fishing industry perspectives. SAMS Report 270-211. Scottish Association for Marine Science, Oban, UK.

Ramirez-Sanchez, S., B. J. McCay, T. Johnson, and W. Weisman. 2011. Surgimiento, formaciín, y persistencia de organizaciones sociales para la pesca ribereña de la península de Baja California: un enfoque antropológico. Región y Socieda XXIII(51):71-100.

Ribot, J. C., and N. L. Peluso. 2003. A theory of access. Rural Sociology 68(2):153-181. http://dx.doi.org/10.1111/j.1549-0831.2003. $\underline{\mathrm{tb} 00133 . \mathrm{x}}$

Sikor, T., and C. Lund. 2009. Access and property: a question of power and authority. Development and Change 40(1):1-22. http:// dx.doi.org/10.1111/j.1467-7660.2009.01503.x

Steering Committee of the State-of-Knowledge Assessment of Standards and Certification. 2012. Toward sustainability: the roles and limitations of certification. RESOLVE, Washington, D.C., USA. [online] URL: http://www.resolv.org/site-assessment/ files/2012/06/Report-Only.pdf

Stull, A. 1991. Nightly foraging movements and den fidelity of the California spiny lobster, Panulirus interruptus, at Santa Catalina Island, California. Dissertation. California State University, Long Beach, California, USA.

Sumaila, U. R. 2010. A cautionary note on individual transferable quotas. Ecology and Society 15(3): 36. [online] URL: http://www. ecologyandsociety.org/vol15/iss3/art36/

Tejeda-Cruz, C., E. Silva-Rivera, J. R. Barton, and W. J. Sutherland. 2010. Why shade coffee does not guarantee biodiversity conservation. Ecology and Society 15(1): 13. [online] URL: http://www.ecologyandsociety.org/vol15/iss1/art13/

Vandergeest, P. 2007. Certification and communities: alternatives for regulating the environmental and social impacts of shrimp farming. World Development 35(7):1152-1171. http://dx.doi. org/10.1016/j.worlddev.2006.12.002

World Wildlife Fund (WWF). 2008. Sustainable seafood: fisheries certification. WWF, Gland, Switzerland.

Worm, B., and R. A. Myers. 2003. Meta-analysis of cod-shrimp interactions reveals top-down control in oceanic food webs. Ecology 84:162-173. http://dx.doi.org/10.1890/0012-9658(2003) 084[0162:MAOCSI]2.0.CO;2 